\title{
Agricultural market information systems in developing countries: New models, new impacts
}

\author{
Franck Galtier ${ }^{1}$ \\ Hélène David-Benz ${ }^{1}$ \\ Julie Subervie ${ }^{2}$ \\ Johny Egg $^{3}$ \\ ${ }^{1}$ Cirad \\ UMR Moisa \\ 73 rue Jean-François Breton \\ TA C-99/15 \\ 34398 Montpellier cedex 5 \\ France \\ $<$ galtier@cirad.fr> \\ $<$ Benz@cirad.fr> \\ 2 Inra \\ UMR Moisa \\ 2 place Pierre Viala \\ 34060 Montpellier cedex 1 \\ France \\ $<$ julie.subervie@supagro.inra.fr> \\ ${ }^{3}$ Institut de recherche et d'application \\ des méthodes (Iram) \\ Parc scientifique Agropolis \\ Bâtiment 3 \\ 34980 Montferrier-le-Lez \\ France \\ $<$ j.egg@iram-fr.org >
}

\begin{abstract}
Market information systems (MIS) developed in two steps in developing countries. A first generation of MIS emerged in the 1980s when most developing countries liberalized their agriculture, and a second generation followed in the 2000s driven by various factors such as the difficulties faced by the MIS of the first generation to reach their objectives, the new opportunities offered by the development of ICT - Internet and cell phones - and the increasing organization of market players (farmer organizations, interprofessional organizations). Contrary to first generation MIS (1GMIS), which were almost all built on the same model, 2GMIS developed many technical and organizational innovations, giving birth to a great diversity of models. What are the main innovations developed by 2GMIS? What are currently the main MIS models? To what extent can these new models allow MIS to overcome the limitations of 1GMIS to reach their objectives (improve markets and/or inform policies through market information)? What do we know on MIS impacts? This article and the special issue it introduces address these questions.
\end{abstract}

Key words: agricultural policy; food security; impact; information system; market; transparency.

Thèmes: économie et développement rural; méthodes et outils.

\section{Résumé \\ Les systèmes d'information sur les marchés agricoles dans les pays en développement : nouveaux modèles, nouveaux impacts}

Dans les pays en développement (PED), les systèmes d'information sur les marchés (SIM) agricoles se sont développés en deux phases. Une première génération de SIM est apparue dans les années 1980 au moment de la libéralisation des agricultures des PED et une seconde génération l'a suivie dans les années 2000 sous l'impulsion de différents facteurs, notamment les difficultés rencontrées par les SIM de la première génération pour atteindre leurs objectifs, les nouvelles possibilités offertes par le développement des TIC - Internet et téléphonie mobile - et l'organisation croissante des opérateurs privés (organisations de producteurs, interprofessions). Alors que les SIM de la première génération (SIM1G) étaient pour la plupart construits sur le même modèle, les SIM2G (qui ont développé de nombreuses innovations techniques et organisationnelles) présentent une grande diversité de modèles. Quelles sont les principales innovations développées par les SIM de seconde génération ? Quels sont les principaux modèles de SIM existant actuellement ? Dans quelle mesure ces nouveaux modèles permettent-ils de répondre plus efficacement que leur prédécesseur aux objectifs qui leur ont été assignés (améliorer le fonctionnement des marchés et/ou nourrir les politiques publiques en information de marché) ? Que sait-on des impacts de ces dispositifs ? Le présent article et le numéro thématique dont il constitue l'introduction tentent de répondre à ces questions.

Mots clés : impact ; marché ; politique agricole ; sécurité alimentaire ; système d'information ; transparence.

Subjects : economy and rural development; tools and methods.
Reprints: F. Galtier doi: 10.1684/agr.2014.0716
To cite this article: Galtier F, David-Benz H, Subervie J, Egg J, 2014. Agricultural market information systems in developing countries: New models, new impacts. Cah Agric 23: 232-44. doi : 10.1684/ agr.2014.0716 
A gricultural market information systems (MIS) are designed to collect, process, and disseminate information on the situation and dynamics of agricultural markets. MIS may have two objectives: improve public policies by helping policymakers take better account of market realities, and render markets more transparent such that resources may be better allocated (more efficiency, greater equity).

The first objective is undoubtedly the oldest. Public grain stocks were already in use in Egypt several millennia ago at the time of the Pharaohs, and ancient Rome and more recently China's emperors developed policies to regulate the price of grain and avoid famines. These policies were very likely accompanied by information systems, although their nature is unknown. By contrast, a great deal is known about the information systems developed in France in the 18th century that accompanied public interventions designed to regulate grain flows. Serge Kaplan (1996) in particular analyzed in detail the attempts made at that time to track prices and estimate flows, stocks and consumer needs. Likewise, subsequent periods of major interventionism by different governments were often accompanied by the introduction of large-scale MIS: this was notably the case in the 1930s in the USA and in France where policies were introduced to guarantee minimum producer prices (Agricultural Adjustment Act in the USA and Offices du blé et du vin in France).

The second objective is far more recent and also more novel. It arose at a clearly identifiable date and place: no trace of any mechanisms employed to disseminate market information to market players can be found before the end of the 19th century in Europe, at which point several agricultural gazettes began publishing market prices. This emergence of market player-oriented MIS is generally attributed to the advent of the telegraph. However, it can also be seen as arising from the history of ideas since the idea of markets not being spontaneously transparent appeared in Europe precisely at that time (Galtier and Clément, 2014).

The idea that information dissemination is necessary for markets to function correctly subsequently migrated fairly rapidly to North America. The idea, however, only spread to other continents a few decades later in the 1980s and 1990s, with the implementation of Structural Adjustment Programs.

At that time, the liberalization of agriculture in developing countries, driven by the IMF and the World Bank, prompted resistance in many countries, particularly for basic foodstuffs such as cereals because of fears that traders would manipulate prices. The setting up of MIS with a view to creating transparent, efficient markets has resulted in a broad consensus among agricultural policymakers and experts. The advocates of liberalization see in MIS the means to render markets more efficient, while the skeptics see in it a means to monitor market failures.

The first generation MIS (1GMIS) were all built on the same model, regardless of country and product concerned. But, by the late 1990s, evaluations showed limited, or even disappointing results, as will be seen later. These 1GMIS faced difficulties that were technical (information unreliable, long dissemination timelines, no analysis, failure to assess the actual use made of the information provided), but also institutional (no incentive for innovation to meet user needs, administrative rigidity) and financial (short-lived project-based funding).

At the turn of the millennium a second generation of MIS (2GMIS) arose from the mutation of certain 1GMIS and the emergence of new MIS (Egg et al., 2012). This step forward seems to have been driven by several factors: the difficulties faced by 1 GMIS but also the new opportunities offered by the development of ICT (Internet and the rapid spread of cell phones in the rural areas of developing countries) and the increasing organization of market players (farmer organizations, interprofessional organizations). These 2GMIS placed more emphasis on the aim of market transparency: although 2GMIS arising from the mutation of 1GMIS did not abandon the aim of informing public policy, they created little innovation in this field, but many did make efforts to better reach market players, particularly through text messages. And as for the new MIS that emerged in the late 1990s or 2000s, almost all are focused exclusively on market player information. They have developed a wealth of technical and organizational innovations such that, unlike 1 GMIS that were all very similar, 2GMIS are based on a wide variety of models.

What are the main innovations that these 2GMIS have developed? What are the main MIS models in use today? To what extent are these new models more effective than their predecessors in reaching the targets they were assigned, and in ensuring their own survival? What is known about MIS impacts? This special issue of Cabiers Agricultures dedicated to MIS addresses these questions. It is the outcome of two research projects, one headed by the Centre de coopération internationale en recherche agronomique pour le développement (Cirad) and the Institut national de la recherche agronomique (Inra) with support from the Agence française de developpement (AFD) and the Technical Centre for Agricultural and Rural Cooperation (CTA), and the other by Michigan State University (MSU) with support from the William and Flora Hewlett Foundation.

This article begins by describing the main innovations 2GMIS have developed and the different models to which these innovations have given rise. It then discusses the limitations of these models before presenting what is known about the impact of MIS. The paper then outlines the main implications for MIS designers and funders. It describes the contents of this special issue devoted to MIS and ends with a conclusion that gives pointers to a number of research avenues.

\section{Recent changes in MIS: an abundance of innovations}

\section{First generation MIS (1GMIS) and their limitations}

The development of MIS in developing countries was associated with the liberal policies driven by the structural adjustment programs of the 1980s and 1990s and supported by international organizations and donors. While states were withdrawing from 
direct intervention in agricultural markets, MIS were to provide instruments both to monitor these markets during their restructuring, and ensure the "transparency" needed for effective competition. These MIS, qualified as first generation, all had a number of common characteristics (Shepherd, 1997): i) each was focused on a country and a group of substitutable products (cereals, livestock, etc.); ii) the information provided was almost exclusively about prices; iii) this information was collected on a sample of markets and its processing was centralized; iv) the same information was disseminated uniformly across the country by radio and other media; v) it was accessible for free; vi) MIS were managed by public services or projects, and were mainly financed by development aid. MIS were therefore based on a single "model" that was applied with very little modulation in all the countries and for all the products considered, and this was rapidly identified as a limitation (Galtier and Egg, 1998).

Although the price data collected played a significant role in monitoring policies and, coupled with other indicators, in triggering emergency aid, the results of this model did not meet expectations, particularly in terms of information for private market players. By the late 1990s, several studies had underlined these limitations (Shepherd, 1997; Galtier and Egg, 1998; Robbins, 2000; Tollens, 2002; Galtier and Egg, 2003).

Technical shortcomings (information inaccurate or unreliable, long dissemination timeliness, etc.) were cited in particular, but the problem also lay more intrinsically in the lack of a mechanism for adjusting the information supply to the needs of market players (Galtier and Egg, 2003).

First, given the non-interactive methods of dissemination used (national radio, billboards), it was difficult for MIS to determine the information needs of market players or their interest in the information provided. Second, the hosting of MIS in government departments or agencies did not provide a favorable context for frequent adjustments. The content of the information itself was poorly adapted to market players as it focused almost exclusively on average prices by locality, was limited to certain product groups (mainly cereals and livestock), and was disseminated uniformly nationwide. Finally, the method of funding MIS (by project) could not be sustained.

\section{GMIS: an abundance of technical and organizational innovations}

The emergence of 2GMIS (by the mutation of certain 1GMIS and the emergence of new MIS) marked the end of the "single model". These MIS developed a multitude of technical and organizational innovations that differed from one MIS to the other. These innovations arose from a concern to better meet the needs of market players and to a great extent were made feasible by the range of technical possibilities offered by developments in ICT. But some innovations were also derived from a greater consideration of the geography of trade, and from a restructuring of the institutional landscape in which professional organizations gradually assumed an increasing role. This emergence of 2GMIS sparked renewed interest in MIS by donors and experts (CTA, 2005; FARA, 2009; FACET, 2010) and resulted in various Master or PhD theses on the subject (Shen, 2009; Wade, 2009; Tongola, 2010; Kizito, 2011).

But five years ago, nobody had an overall view of these innovations. Researchers at Cirad and Inra therefore, as part of the research program mentioned above, undertook to conduct an email survey of 85 MIS (53 in Africa, 18 in Asia, 9 in Latin America and the Caribbean, 1 in North America, and 4 worldwide). The questions focused on the main features of MIS at the time of the survey, and on changes since their inception. In all, 31 valid replies were received, 94\% of which from MIS in sub-Saharan Africa and the Indian Ocean. The results of this survey provided more knowledge on and a better understanding of these changes and were used to analyze MIS strong points and limitations (DavidBenz et al., 2012).

They fueled the discussions held at two workshops designed to promote exchanges between researchers, MIS, donors, policymakers and professional organizations (the first in Mont- pellier in March 2010, the second in Bamako in November 2011).

The changes made concerned the various aspects of MIS organization and operation.

\section{Objectives focused on market players}

The vast majority of MIS innovations were very clearly aimed at market players, and thus today the aim of increasing market efficiency by providing market players with information is shared by all MIS. In addition, the few innovations designed to better assist policy decisions mainly concern mechanisms promoting the involvement of private players in this process (for instance by feeding multi-stakeholder consultation forums on a national or local scale [David-Benz et al., 2014; Moustier et al., 2014]).

\section{A diversification of institutional positions}

The setting of an agenda to link small farmers to markets, and the growing awareness among farmer organizations of marketing issues, have diversified the institutional shape of 2GMIS. Many MIS are now supported by professional organizations, NGOs close to these MIS, or private service provider companies, rather than by public bodies.

\section{Geographic scales sized to fit the markets concerned}

While 1GMIS intervened almost always at the national level, 2GMIS have tended to be sized to match the geography of trade in the products concerned and, in some cases, to support regional integration policies. This led to the emergence of regional MIS (AMITSA and RATIN in East and Southern Africa), while others have developed on sub-national scales (e.g., Manobi in Senegal, SIEL in Madagascar) or have been decentralized by disseminating different information in different areas of the country (such as OMA in Mali [Staatz and Dembélé, 2004; Egg et al., 2014]).

Also, an inter-connection of different MIS is developing through networks (RESIMAO and Afrique Verte in West Africa) or web platforms (Esoko). 


\section{Increasing use of ICT in collecting and disseminating the information}

The success of mobile telephony in rural areas, and the spread of the Internet, have led to major technical developments in MIS. Whereas data transmission from collection point to central unit could in the past take several days, it is increasingly achieved in real time, and the risk of errors has been reduced by the disappearance of multiple data entries and the use of automated processing. To reduce data collection costs, some 2GMIS are attempting to do away with survey staff by asking operators themselves to supply the information. However, relying solely on market players can cause problems of reliability (with the risk that prices reported are more loss-leader prices than actual prices) and regularity (if information is provided on a purely voluntary basis). These problems however can be resolved (they may in particular be partially offset by a large number of informants or by establishing control procedures). In fact, although this method is still rarely used by MIS, it is expanding in other types of information systems (such as the Observatoire de l'alimentation - Food Watch in France).

For the dissemination of their information, 1GMIS relied mainly on national radio, billboards, the press and, for policymakers, on analysis reports. These very inclusive communication channels had three major drawbacks: they restricted the MIS to disseminating only a very small portion of the information collected, dissemination timelines were long, and they were unable to determine to what extent the information disseminated was received by potential users. 2GMIS have deliberately turned to cell phones and the Internet to develop new channels for information dissemination. These technologies have corrected some of the weaknesses of the media previously used insofar that: i) a great diversity of information can be collected and made available in a very short time; ii) it is the users who select the data that interest them (from the mass of information made available); and iii) by this selection process the users indicate which information is useful to them, thus providing MIS with indicators they can use to shape their information supply.

\section{Expansion of the type of information and the range of products tracked}

Thanks to the technological possibilities offered by ICT, the information proposed by MIS has been greatly diversified in efforts to help market players in decision-making. Whereas 1GMIS collected and disseminated mainly average prices by locality, many 2GMIS go much further. In order to highlight real opportunities for transactions, many 2GMIS distinguish between the different qualities of the products tracked and the different levels of transaction. The dissemination of personalized information has been developed to facilitate direct links between buyers and sellers: nominative purchase and sale proposals are increasingly common (KACE in Kenya), purchase price charged by processing enterprises (ZNFU Zambia) or volumes stored in different receipt system warehouses (EAGC in Kenya). Some MIS monitor flows or (more rarely) stocks of agricultural product on a local or regional scale. Some also disseminate information to help operators plan their farming operations or anticipate price changes (meteorological data, situation on international markets or the markets in neighboring countries), or even - but this is much rarer-attempt to make price forecasts (RONGEAD Cashew Nut MIS in Côte d'Ivoire). Also, 2GMIS cover a far more diversified range of products than their predecessors that were often limited to following a few strategic products such as grain or livestock.

\section{A more integrated approach to market services and institutions}

Whereas 1GMIS restricted their activities to the production and dissemination of market information, many 2GMIS offer additional services (directly or through their hosting organizations) that aim to link farmers to markets or improve market performance. They may, for instance, provide support for farmer organizations to promote collective marketing (MIS Cashew Nut in Côte d'Ivoire), facilitate access to different services (credit, transportation, inputs, agricultural advice, etc.) or ensure enforcement of trade commitments (commercial arbitration, information on the reliability of potential business partners, clearing houses). EAGC in East Africa is a good example of an organization seeking to develop such a multi-service approach. Some MIS provide brokerage services or are even a component of a commodity exchange. ECX (Ethiopia) is undoubtedly after SAFEX in South Africa the African commodity exchange that offers the most comprehensive range of services: sophisticated auction system, but also a quality classification system, a warehouse receipt system, a system to guarantee contract enforcement, dissemination of quotes in real time (by electronic display panels and text messages); ECX receives tens of thousands of queries per day by text message and interactive voice recognition systems $(\mathrm{IVR})^{1}$.

\section{The search \\ for sustainable financing}

The lack of sustainable financing was one of the weaknesses of 1GMIS, with their resources stemming primarily from projects funded by donors. By targeting market players and using cell phones as the primary media of dissemination, the ability of MIS to generate resources by invoicing information received by users emerged as a new opportunity. Some 2GMIS, particularly those supported by private companies, state that they intend to sell information to cover their costs (but, as we shall see later, they are as yet a long way from achieving this). At the same time, many public MIS have managed to secure funding by including their costs in the State budget.

\section{The different MIS models}

The various innovations and developments observed are not independent

\footnotetext{
${ }^{1}$ Yet this model is not easy to reproduce as it functions well only for export products, for which it benefits from a particularly favorable regulatory context (only the coffee purchased on the ECX is allowed to be exported from Ethiopia).
} 
one from the other. They stem largely from the decision taken by each MIS to give priority either to information for policymakers or for market players. In the latter case, the information given may be split into two, i.e. that intended to improve market efficiency, and that intended to improve equity (by reducing information asymmetries). This is why we will hereinafter describe MIS types based on institutional position which appears to be the most discriminating factor as it shapes the major objectives of an MIS and shapes the technical and organizational methods chosen. Four MIS models were identified in this way (the first two are the most common).

\section{Public MIS}

Most of public MIS are derived from the first generation, but have often been substantially upgraded (incorporating the use of ICT and shifting towards market players). They are hosted in public institutions and are funded (at least partially) by the state budget. When they serve the dual purpose of improving public policies and ensuring market transparency, their products and the methods they use to disseminate information are particularly suited to institutional players. These MIS mainly intervene on a national scale, i.e. that at which policies (for now) are developed, but regional networks of public MIS are also found and these aim to support the emergence of regional policies (see RESIMAO in West Africa). These MIS may cover a broad range of products or may be focused on "strategic" products (in terms of food security, foreign exchange earnings, etc.). Although they rarely provide services other than information. They have long based their dissemination of information on "conventional" channels (written bulletins, radio bulletins, billboards), they are also increasingly likely to use cell phones in order to better reach market players.

\section{MIS supported by professional organizations and NGOs}

The main aim of these MIS is to inform market players about production and trade opportunities. Some of them may also aim to strengthen the advocacy capacity of its hosting organization when the size of this organization and its "representativity" on a national or regional scale lend it sufficient legitimacy to intervene in the policy-making process. These MIS may intervene on sub-national, national or regional scales depending on the geographic extension of the host organization. These MIS are generally financed to a great extent by external supports (donors, projects, NGOs). They seek to provide a broad range of information in short timelines, their goal being to provide assistance to farmers, farmer organizations, traders or consumers on buying and selling decisions, but also in some cases on production decisions. They may be specialized or cover a broad range of products. They prefer ICTbased methods of dissemination (particularly cell phones), but have not done away with the more traditional methods (radio bulletins, billboards). Information dissemination is not the main goal of the organizations that support these MIS. Thus - and this is probably one of their specificities these MIS are generally components of broader marketing support programs that provide a range of other services (credit, storage, training, agricultural advice, etc.). In some cases, additional services aim specifically to support collective marketing (collective purchase of inputs, collective sale of agricultural products, etc.).

\section{MIS linked to a commodity exchange}

These may be exchanges, in the strict sense, which by the transactions that take place within their walls generate prices and disseminate information on these prices (this is the case of the ECX in Ethiopia). Or they may be institutions that aim to improve trade by facilitating meetings between buyers and sellers and which at the same time collect and disseminate price information. This second type of MIS is often associated with other complementary services and in this sense is similar to the MIS model supported by professional organizations or NGOs (this is particularly the case of MIS developed in West Africa by the Afrique Verte
NGO, and KACE in Kenya). These MIS associated with commodity exchanges also often involve business representatives in their governance structure, even though they do not have the legal status of an interprofessional organization.

\section{Private MIS}

These are MIS supported by private enterprises not involved in agricultural production or marketing. Their goal is to produce marketable information for private market players such that they may improve their production and trade decisions, thereby increasing market efficiency. They base their activity on their considerable ICT skills, exploring a vast range of technological innovations that allow them to offer the most comprehensive and flexible information possible, in order to be attractive. Their quest for high technical performance, and the need to generate their own resources, drives them to prefer cell phones and the Internet as their main means of dissemination. Although their business plans ultimately tend toward a self-financing capacity, at present they are able to cover only a small fraction of their costs by charging users for information. Their main resources stem rather from donors and sometimes from selling the expertise and technical tools they have developed in ICT.

\section{The limitations of today's MIS}

Despite the considerable changes undergone by MIS over the past two decades, and the diversity of innovations that have been developed, they still face many challenges. Their current limitations may be split on the basis of three objectives: i) improve public policies; ii) increase market efficiency; iii) enhance equity by reducing information asymmetries.

\section{Their goal of assisting the public policy-making process tends to be neglected}

Currently, most public MIS merely disseminate raw information (tables, 
graphs, etc.), accompanied at best by descriptive comments. In addition, they restrict themselves to disseminating these notes and this information through channels and in formats that primarily reach public policymakers without involving representatives from professional organizations and civil society, even though these are increasingly involved in policy-making. Meanwhile, MIS supported by professional organizations and NGOs are mainly focusing their efforts on disseminating information for private decision-making. And though some of these organizations are involved in political lobbying, their MIS usually do not produce information for this purpose.

\section{An abundance of innovations but no tools for monitoring and evaluation}

Improving information supply is probably the area in which 2GMIS have contributed the most. Cell phones and the Internet have been decisive in reducing information collection and dissemination timelines, improving data quality, increasing the diversity of the information provided, and the frequency of its dissemination. But although many MIS have broadened the range of information they cover, this is not the general case and some information key to improving decisions on where and when to buy and sell is often unavailable or unreliable (particularly stocks, flows, transport costs).

If MIS are to improve their information supply they also need to know to what extent the information they provide is of interest to market players. But many MIS have not implemented a mechanism to generate this feedback. And even when user queries can be tracked (especially in SMS-based diffusion schemes) this information is rarely analyzed and used to adjust MIS information supply (in fact, this information in most cases remains at the telephone company).

Finally, even with access to better information, many players are unable to change their practices because of the constraints to which they are subject (access to credit, access to means of transportation, etc.). Although some MIS provide services in addition to information in order to overcome these constraints (or are part of an organization that provides such services), this is still far from being the general case.

\section{Risks of exclusion due to ICT}

Although the provision of more information can reduce information asymmetries (and by this way contribute to greater equity), this only holds true if the information is accessible to the weakest players (especially smallholders). But most of the information dissemination methods used by 2GMIS (cell phones, the Internet) may instead increase inequalities by excluding those who do not have access to these technologies (lack of any means to acquire them, access to networks, or the cognitive ability to use them judiciously). Access to mobile telephony and the Internet is still very uneven in Africa and in developing countries in general, even if it is expected to grow and although costs are gradually falling (in 2010, 86\% of households in South Africa and Senegal had a cell phone, but only 16\% in CAR and 21\% in Mali, [World Bank, 2012]). This problem of exclusion is further exacerbated when MIS charge users for the information they provide. Finally, note that beyond the question of cost, exclusion may also arise from the cognitive capacity of the weakest (and least educated) players to access the information (many farmers are illiterate and the interfaces employed are sometimes complex) and understand it. Anyway, support for user training is still largely ignored.

\section{Financial sustainability: a transversal issue for all MIS}

Financial sustainability is key for all MIS. MIS supported by professional organizations are highly dependent on external project-based funding. MIS costs may sometimes be covered by the other activities of the host organization (but often these other activities themselves depend in part on projectbased funding). The situation is not very different for private MIS, despite the fact that they sell most of their services: the contribution made by users is marginal and they are still primarily funded by donors (see for example KACE in this issue) or NGOs (as is the case for Esoko-Ghana). The costs of collecting, processing and disseminating comprehensive and diverse information are high, while the most vulnerable players have very little capacity to pay for it. Public MIS are also in a difficult situation. Granted, most of them today have secure state budget funding, but this is often insufficient for truly satisfactory operation (and certainly precludes the possibility of innovation).

\section{What is known about the impacts of MIS?}

MIS are expected to have multiple impacts but major methodological difficulties are encountered in their measurement (Staatz et al., 2014).

First, MIS may help improve public policy by helping policymakers better consider the market situation and its dynamics. Second, MIS may lead to improved production and marketing decisions and thus improve market efficiency and resource allocation. Third, MIS may strengthen the bargaining power of agents who are usually uninformed about prices, and thus lead to an improvement in equity. Note that although impacts on efficiency and equity are increasingly the topic of empirical analyses, to the best of our knowledge impact on public policy has never been subject to a quantitative assessment. In what follows we will consider successively the impact of MIS on public policy, on market efficiency and on the value added distribution between agents.

\section{Some (unmeasurable) impact on policy}

Providing decision-makers with information on market situation and dynamics is likely to improve the design, implementation and evaluation of public policies. In a context of increasingly volatile agricultural markets and recurrent food crises, particularly in the Sahel and the Horn of 
Africa, this function of MIS is obviously primordial. Have MIS significantly influenced public policy by helping decision-makers take greater account of market realities? Have they thereby improved the welfare of people in developing countries? It is extremely difficult to answer these questions in a quantitative manner. To evaluate this type of impact, we would need to be able to observe policies implemented in the absence of MIS and compare them with policies implemented in the presence of MIS. Although it may be possible, by modeling, to simulate (with sometimes very large error margins) the impact of a hypothetical policy, it is impossible to determine the policies that would have been implemented had policymakers been provided with less information. This is why no impact assessment of this type has ever been conducted.

However, it may be stated that the information collected by MIS does play an important role in public decisionmaking. In Madagascar, for example, MIS data on the situation of the rice market were fed into a consultative platform attended by representatives of private market players and various ministerial departments. Although this type of platform has a purely advisory role, it clearly contributes to the development of i) a shared diagnosis of the situation and ii) policy options on a national or local level (David-Benz et al., 2014; Moustier et al., 2014).

In certain cases, MIS play a vital role in building indicators used to trigger public interventions. This for instance is the case for price stabilization policies (Galtier, 2013). And also for the activation of emergency aid: some MIS feed information into Early Warning Systems (EWS) that provide indicators used to trigger public support in crisis situations (Egg, 1999) ${ }^{2}$.

\section{Documented impact of cell phones (but not MIS) on market efficiency}

Theoretically, when agents are comprehensively informed on market

\footnotetext{
${ }^{2}$ Some experts offer to go further by building early warning indicators based solely on price data (Araujo et al., 2012) and the World Food Program is attempting to put this idea into practice.
}

prices, they are able to exploit all the opportunities for arbitrage - arbitrage in time, in space and between marketable products - and this results in seamless market integration and price stabilization. Many empirical studies have been devoted to analyzing the spatial integration ${ }^{3}$ of agricultural markets in developing countries (Fackler and Goodwin, 2001; Rashid and Minot, 2010). Some studies showed that price differences between markets located far apart decreased over time. However, these studies do not show to what extent this improved market integration was due to the emergence of MIS, to the boom in mobile telephony (together with that of 2GMIS) or to other aspects of improved marketing conditions such as the liberalization of agricultural markets (concomitant to the development of 1GMIS), improved infrastructure or the development of market institutions.

To the best of our knowledge, only two recent studies have addressed the question of the impact of information on market integration. Both focused on mobile telephony. Jensen (2007) highlighted the impact of introducing cell phones among the fishermen of Kerala in India ${ }^{4}$. The results showed that the GSM network had a very significant impact on the spatial homogenization of prices. They also showed the virtual disappearance of waste, a near-perfect exploitation of spatial arbitrage opportunities, and spectacular price stabilization. It should however be noted that the markets analyzed by Jensen were initially particularly inefficient: given that the fishermen had no access to information when at sea, they randomly chose the coastal market at which to sell their fish, and this situation was characterized by shortages in certain markets and surpluses in others; as fish is a perishable product, they could not store surpluses and had to throw them away. But such a situation of inefficiency is very rare in the agricultural markets of developing countries. Aker (2010) employed the same methodological approach to

\footnotetext{
${ }^{3}$ To the best of our knowledge, no empirical studies have ever been conducted on temporal arbitrage or arbitrage between products.

${ }^{4}$ The author uses the gradually expansion of the GSM network as a natural experiment and over a given period compares markets in areas covered with those in areas not covered.
}

estimate the impact of introducing cell phones on grain market integration in Niger. Her results showed a significant reduction in absolute price differences between market pairs. They also showed that traders operating in the markets located within the areas covered by the GSM network were present at more markets, had more contacts, and sold on more markets (one additional market on average). These studies confirmed that information plays a decisive role in improving market efficiency. They also suggest that market integration may be achieved solely through the use of cell phones, without the introduction of an MIS.

\section{Heterogeneous impact on farmer incomes}

Beyond its impact on price dispersion, an MIS may have an effect on equity, which for some MIS is the principal aim (Poulton et al., 2000; Ferris et al., 2008). An MIS may in particular decrease the market power of certain agents in situations of oligopsony (when only a few buyers are present). In many countries of sub-Saharan Africa farmers customarily sell their agricultural products to collectors who often travel back and forth between the villages where they buy and the markets where they sell the products they have collected. Unlike farmers, who are often cut off from marketplaces, these collectors are well informed about current prices and can take advantage of this information asymmetry to offer farmers low prices (Wade et al., 2004; Fafchamps and Hill, 2008; Mérel et al., 2009).

Introducing a MIS would in this case allow farmers to obtain a higher price by: i) intensifying competition between collectors; ii) generating better spatial arbitrage (some farmers could for instance sell on markets further away); and iii) increasing farmers' bargaining power (this last impact would not result in an increase in the economic surplus generated by trade, but in a change in its distribution). Similarly, MIS may give better informed consumers the chance to obtain lower prices.

Studies on the impact of MIS on user prices and incomes have mostly focused on the business performance of small farmers. The methodology 
employed in these published papers is based on recent developments in micro-econometric methods of impact analysis (Duflo et al., 2008; Todd, 2008; Imbens and Wooldridge, 2009).

Here we present the four most recent studies published in scientific journals. The paper by Jensen (2007) cited in the previous section showed that introducing cell phones boosted the profits and income of all fishermen (users and non-users of mobile telephony) due to improved market efficiency, but the greatest increase was seen among users. Svensson and Yanagizawa (2009) estimated the impact of a Ugandan MIS, Foodnet ${ }^{5}$, that broadcasts information by radio on the farmgate price paid to maize farmers. Their results showed a marked improvement in farmer business performance: a $15 \%$ increase in maize selling price and a 32\% increase in the proportion of production sold, considering all crops together. The authors attributed these effects to the greater bargaining power of farmers over buyers. In an entirely different context, Goyal (2010) assessed the impact of introducing Internet kiosks in villages of soybean farmers in India. This technology informed the farmers of the price at which their product was being sold on the different wholesale markets, and the price at which a private processing company offered to buy the product (directly from farmers). Here again the results suggest that the information provided increased the market power of farmers who were previously faced with collusion between the few traders on wholesale markets. Fafchamps and Minten (2012) for the first time estimated the impact of a text message-based 2GMIS by a randomized controlled evaluation ${ }^{6}$. They studied the impact of the Reuters Market Light MIS in India and found that it had no significant impact on the farmers in their sample. However, as the authors point out in their conclusion, it is

\footnotetext{
5 This MIS was covering 21 of the 56 districts in the country.

${ }^{6}$ A randomized controlled evaluation is based on randomly selecting beneficiaries for an MIS access program. This method in principle ensures that the beneficiaries group and the nonbeneficiaries group have similar characteristics (and can therefore be directly compared).
}

possible that no improvement in farmer prices could be expected as most farmers sell on auction markets where they already receive a "fair price" for their products. Finally, Subervie and Galtier (2014) together with Courtois and Subervie (2014) provide the first analysis ever made of the impact of a 2GMIS in subSaharan Africa. Their analysis highlights the impact of a program based on the Esoko MIS in Ghana on the selling prices of farmers benefiting from the program in 2009. The results indicated that these farmers received higher prices for maize and peanut about 10\% more for maize and $7 \%$ more for peanut - than they would have had they not been taking part in the program. Thus, even this still recent literature yields contrasting results. Too few empirical studies have yet been conducted to draw general conclusions on the magnitude of the impact that may be observed. Many similar studies are in progress (Nakasone et al., 2014).

This review of MIS impact studies shows that only one of the potential impacts of MIS can be assessed in a rigorous manner, i.e. impact on MIS information users (here empirical studies have detected moderate or insignificant effects, depending on the case). By contrast, the impact resulting from improved policies (which is expected to be very substantial) cannot be quantified, and the same may be said to some extent for impact on market efficiency.

\section{Implications for MIS}

The analyses presented above, indicating the potential of MIS, their limitations and what is known of their impacts, quite naturally prompted us to make a number of suggestions and recommendations to improve MIS and strengthen their impacts (Galtier et al., $2012 \mathrm{~b})$. The main recommendations are set forth hereafter.

\section{Promote networking and a sharing of experience}

Given the multitude of technical and organizational innovations that have been developed over the last 15 years, a great diversity of MIS are operating today. This diversity is not a problem: the studies presented in this issue show that it would be futile to seek out an optimal model for MIS. No such model exists: the most appropriate model depends on the aims of the MIS and the context in which it operates. The diversity of MIS is instead an as yet largely unrecognized and largely untapped asset. By promoting the sharing of experience, networking MIS would exploit the tremendous resource that constitutes the diversity of MIS methods and practices. Such a network already exists in the Americas: the Market Information Organization of the Americas, or MIOA. The groundwork for an equivalent network has already been completed for Africa (see http://www.sim2g.org/fr/).

\section{How can MIS impact on public policy be enhanced?}

It should be noted that almost all MIS today tend to focus primarily on information for private market players (and the aim of market transparency): MIS derived from the first generation have not given up on the aim of informing public policy, but they have developed very little innovation in this area, and the new MIS do not generally include this in their aims (with the notable exception of RATIN in East Africa and the OdR in Madagascar). This may be considered to be regrettable as high quality information is key to policy design and implementation (even if it is difficult to isolate and measure its impact).

Were MIS to produce market outlooks and briefs analyzing the effects of different policy options, they could doubtless contribute effectively to enlightening decision makers. But it is obvious that to produce such analyses MIS would need to possess sound analytical skills (or collaborate with higher education and research establishments, as is the case for OMA in Mali).

MIS can be valuable tools to stimulate debate on policies, especially if they disseminate their analyzes not only to public policymakers but also to representatives of professional organizations. And also if they use more interactive methods of dissemination (presentations/discussions, radio or 
television programs with interviews by journalists and calls from listeners, etc.). In this respect, the most promising forms are those where MIS are involved in forums attended by representatives of market players and government (see the case of the Observatoire du Riz in Madagascar). Additional training or capacity building actions can be employed to enhance the involvement of professional organizations and increase their participation in the debate. Regarding MIS hosted by professional organizations, it is their responsibility to organize internal discussions (within the organization) to help it define its position and its advocacy action.

MIS could also contribute to rendering policies more predictable by informing market players of measures that are to be implemented (thus reducing the distortions they may generate on markets [Jayne et al., 2006; Maître d'Hôtel et al., 2012]).

\section{How can MIS impact on market transparency and efficiency be enhanced?}

How can the information supply be improved to better inform market players of trading opportunities? This could include an increase in the accuracy of the price information disseminated by distinguishing more the qualities and the transaction level, or even by disseminating the buying or selling prices of specific market players. The price information provided could be supplemented by other variables (including main marketplace supply levels, as well as stocks, flows and transport costs that are all key to improving spatial and temporal arbitrage). In addition, some of this information could usefully be disseminated in aggregate form, making it directly usable, e.g. for traders involved in regional or international markets, by providing cost prices for imported or exported goods (calculated directly from the price in the country of origin or the destination country, exchange rates and transport costs); for products whose market fluctuates very rapidly, by providing short-term trend indicators to accompany the "price of the day", which rapidly becomes obsolete.

\section{How can MIS impact on equity be enhanced?}

What can MIS do for the poor? First, MIS can make markets more competitive (see previous point), and can thus help the poor benefit from better prices even though they do not themselves directly receive the MIS information. Second, MIS can strengthen the bargaining power of the poor by providing them with information on prices and trading opportunities. Here, the challenge for MIS is to find a suitable method to convey the information, given that the methods of dissemination most commonly used by 2GMIS (cell phones, websites) are based on technologies to which the poor may not have access. Two options are therefore possible. The first is to use inclusive methods of dissemination (such as local radio) in addition to ICT tools. The second option is to develop support strategies that facilitate access to ICT and reduce the cost of this access. This may be based on: i) making users aware of the information services offered and training them to use these services such that they may access the information; ii) collaborating with NGOs such that they cover the costs for certain people (as was achieved by the Esoko MIS in Ghana); or iii) developing USSD platforms that allow users to obtain a broad range of information by means of a simple cell phone and the cost of a text message. But this does not resolve the difficulty of transmitting information to the illiterate as voice systems are more expensive than texts. In addition to conveying data to the poor, another challenge must be met: their ability to interpret these data and use them in an effective way in their cropping and selling decisions must be strengthened. This can be achieved by training but also through radio educational programs (explanations of market dynamics, forecasts, tips, information on the MIS itself or related services, etc.) or interactive programs (minidebates, listener phone-ins).

\section{How can MIS capacity to adjust to user needs be improved?}

MIS information supply can also (and perhaps can above all) be improved by setting up a system to provide feedback on the use made of the information provided. Such feedback would enable MIS to adjust continuously their information supply to match market needs (by regularly providing new types of information and retaining only that which prompts real interest among users). This feedback could be facilitated by using certain "interactive" methods of dissemination (cell phone, website or radio broadcasts with listener phone-ins) and certain types of institutional hosting (particularly professional organizations). It could also be generated by ad hoc mechanisms (periodic surveys, regular meetings with a panel of market players, etc.). But this feedback would only be useful if organized, with user information being regularly collected, analyzed and used to adjust MIS information supply.

\section{How can the constraints of market players be better taken into account?}

Information is certainly necessary but alone is not enough to improve market efficiency or reduce asymmetries. To make information actionable by market players, it often needs to be combined with additional services (or investment in infrastructure), the nature of which depends on market players' constraints. These services may include credit, storage, weight or quantity measurements, quality grading systems, agricultural advice, transport infrastructure, etc.

MIS supported by professional organizations and NGOs are doubtless the best placed to provide these services, as illustrated by the case of RATIN or, with a different approach, MIS backed by a commodity exchange, as is the case for the Ethiopian Commodity Exchange (ECX).

\section{Appropriate use of impact studies}

Although they arouse the interest of donors and are the subject of a growing number of studies, microeconometric impact analyzes do not provide a full assessment of MIS. These assessment methods are not applicable for all types of MIS, or for 
all contexts (Staatz et al., 2014). When they can be implemented, the validity of their results is only conditional: the results are valid only in the context of the study, i.e. in the country studied, in the sample considered, and according to the macroeconomic conditions prevailing over the study period (Heckman, 2008). In addition, when impacts on income are measured, they usually prove to be fairly limited, reflecting the fact that players on agricultural markets in developing countries already have their own information systems (Egg et al., 1996) but also that they face many constraints (credit, transport, etc.) that prevent them benefiting fully from the additional information disseminated by MIS. This does not imply that MIS are worthless, but rather than making their information really useful means providing additional services (see above). Finally and most importantly, current assessment methods do not consider all the potential impacts of MIS. For instance, MIS often contribute substantially to public policy, but this impact cannot be measured. Yet this impact is obviously important. This means that impact assessments should not be used as sole criteria for deciding whether or not to fund an MIS. It would be far more relevant to use these assessments as management instruments, enabling MIS to better understand the impact of the information they provide.

\section{How can MIS be made financially sustainable?}

There are no miracle solutions to this recurring concern. Increasing the number of users by expanding MIS product range and geographic coverage could improve financial viability while maintaining modest access costs. But to be effective, MIS must adapt to the particularities of each market, and this reduces the relevance of large-scale uniform schemes. At least partial recourse to subsidies therefore seems difficult to avoid. This can be justified by the fact that since information contributes to public policy decision-making and to improving equity, it has the status of a public good. A balance must therefore be found between basic information (that should be accessible by everybody) and more detailed or specific information like market analyses or individual counseling (that could be invoiced). This may be achieved through publicprivate partnerships (Weber et al., 2005) or by partnering MIS of different "models" to make the most of their complementarities. MIS may also provide other revenue-generating services such as brokerage, storage, or guidance for the drafting of contracts between producers and food processors, etc.

\section{Content of this special issue}

This special issue of Cabiers Agricultures offers a selection of original articles that aim to shed light on the questions raised in this introductory paper on MIS innovations, models, and impacts.

It kicks off with an article by Galtier and Clément (2014) that places the recent changes in MIS in a historical perspective. Basing their study on the work conducted by Michel Foucault, the authors begin by retracing the steps that led to the emergence in the 19th century of the first MIS intended to guarantee market transparency (with particularly in the 16th century the introduction in France and England of a policy to "stage" the abundance of cereals). The authors then analyze the factors that shaped MIS changes from the 19th century till today, and in particular show how institutionalist ideas have broadened the concept of market transparency.

This is followed by six articles, each presenting a particular MIS: its operation, the difficulties it has faced, and the solutions implemented to overcome them. These case studies illustrate the different innovations and the different MIS models presented above. Ngombalu and Massila (2014) present the case of the Regional Agricultural Trade Intelligence Network (RATIN). This MIS developed by the Eastern Africa Grain Council is a typical example of a 2GMIS supported by a professional organization: it mobilizes ICT (text messaging and the Internet) to disseminate information. The information it offers its members is integrated within a multitude of other market services (warehouse receipt systems, electronic trading platform, training and capacity building, dissemination of quality standards, support for commercial arbitration, organization of fairs, etc.) and develops advocacy actions to generate favorable policies for regional trade. Its main novelty is that it operates on a regional scale.

Mukhebi and Kundu (2014) analyze the case of the Kenya Agricultural Commodity Exchange (KACE). This is a typical example of an MIS managed by a private company and based on a business model focused on the supply of invoiced services (even though it is still today largely funded by public money). KACE has followed a very novel trajectory: it was first established in 1992 as a "conventional" commodity exchange based in Nairobi. It was then decentralized (with the creation of micro-commodity exchanges which were later franchised) in the different areas of production across the country. Today (despite its name), it operates more like an MIS than an exchange: volumes traded on microexchanges are still very small and most $\mathrm{KACE}$ price information is collected elsewhere.

Egg, Dembele and Diarra (2014) analyze the transformation of a 1GMIS (Market Information System for cereals in Mali or SIM) into a 2GMIS (Agricultural Market Watch or OMA). This upgrade was based on two major innovations: a change in institutional hosting (while the MIS was based in the grain marketing board, the OMA is currently based in the Chambers of Agriculture association) and decentralization with some choices regarding what information is collected and disseminated being made at a local level.

David-Benz, Rasolofo and Andriamparany (2014) focus on one of the rare cases of a public MIS that has developed an innovative approach to providing support for policy-making. This MIS is called Observatoire $d u$ Riz (Rice Market Watch). It was founded in Madagascar in 2005 together with a governance mechanism: The Rice Industry Consultation and Management Platform, which brings together policymakers and representatives of private market players. Although the power asymmetry between farmer representatives and those representing 
dominant market players has limited the balanced consideration of each party's objectives, the authors show that these two institutions have created the beginnings of public-private partnerships for price regulation and have led to more transparent and rational management of interventions.

Moustier, Nguyen Thi and Hoang (2014) also address the question of combining an MIS with an institution for multi-stakeholder dialog, in this case on a local scale. They describe the MICS (Market Information and Consultation System) established in Hanoi in 2002 as part of a development project in response to marketing constraints expressed by vegetable growers. The initial aim was above all to establish a diagnosis, using workshops, and develop collective strategies, but farmers soon asked for a price monitoring system to be set up, with prices broadcast on television. In a context where debate is not a customary practice, and where farmer organizations are weak, where extension services have no real organizational capabilities, consultation workshops proved to be more difficult to sustain than price dissemination.

Unlike the above, the article by Vergara, Wang and Zuba (2014) does not describe an MIS that exists today. It is a reflection on the opportunity for MIS in developing countries to incorporate a module to model agricultural risk. Such modules already exist in the United States and China where they are used primarily by the agricultural insurance sector, but the authors argue that they can also provide farmers and other market players with information useful for production, marketing, debt and risk management decisions.

The last three articles in this issue deal with the impact of MIS.

Staatz, Kizito, Weber and Dembélé (2014) list the methodological challenges of assessing the different potential impacts of MIS on the balance of power between farmers and traders, on the ability of market players to seize the best trading opportunities, and on the design and implementation of public policies. They identify four major challenges: selecting appropriate indicators; establishing a baseline; distinguishing between direct impacts of ICT and impacts of MIS based on these technologies; overcoming the problem of causal inference.
Kizito and Staatz (2014) propose a method for discussing the potential effects of price information on welfare (defined in their article as the sum of farmer and consumer surpluses). For this they use a simple partial equilibrium model in which the introduction of MIS information helps economic agents to improve their price expectations. This method, however, has many limitations insofar that it reduces MIS information (weekly prices on many markets) to a single annual price. Its application to the Agricultural Market Watch (OMA) in Mali (as proposed in the article) is rather theoretical given that at present this MIS does not provide any price forecasts.

Finally, Ferris (2014) reports the main results of a qualitative survey on the use of information provided by the Ugandan public MIS. This survey was conducted among a sample of more than 450 stakeholders in the agricultural sector. It shows that farmers use MIS data to monitor market changes over time, and in consideration of this decide on what crops to grow and when and where to sell their products.

\section{Conclusion}

Although recent research has led to a better understanding of how MIS function and the impact they have, some aspects are still poorly understood and need to be addressed in future research. Below are three aspects we consider to be the most important.

The first concerns the role of the additional services provided by many 2GMIS (or the institutions hosting these MIS). As we saw in the first sections, the currently dominant idea is that the provision of additional services (credit, agricultural advice, collective marketing, warehouse receipt systems, brokerage, etc.) may enhance the use of MIS-disseminated information by lifting some of the constraints faced by market players. However, this effect is far from being automatic and warrants study in more detail. This means further analysis of the factors impeding the integration of information in decision-making processes, particularly the constraints that reduce market players' room for maneuver and individual factors that limit their capacity to analyze and use MISdisseminated information.

The services offered to farmers or other market players may also increase market transparency through another channel. It is recognized that information is spontaneously disseminated by marketing behaviors. This phenomenon is well known to economists (Hayek, 1945; Smith, 1982; Kirzner, 1992) and traders (who for example adjust their price to the volume of traffic on a marketplace or the rate at which their stock is selling, [Galtier, 2002]). As the quality of this spontaneous dissemination of information within markets appears to depend on the institutions that create the framework for transactions (Galtier, 2002; Galtier et al., 2012a), information dissemination (by MIS) is not the only possible action to increase market transparency: action is also possible on market institutions to render them more efficient in terms of information dissemination. And this is what certain services offered to market players can do. For example, establishing grades and standards (to classify products into homogeneous quality groups), warehouse receipt systems (to increase the information level on private stocks) or commodity exchanges is likely to greatly increase market transparency. This alternative approach (which is also complementary to that of MIS) should be incorporated into the analysis.

The second aspect is that the negative impacts of MIS should be taken into account when assessing their overall impact. It is now known, for instance, that more information can generate perverse effects (Galtier, 2002), but these effects have never in the past been included in MIS impact assessment studies. First, information dissemination may polarize expectations and thus inflate bubbles or cause panics or cobweb dynamics (Orléan, 1989). This is thought to have occurred in the UK when information provided by an MIS caused an influx of agricultural commodities on certain markets and a collapse in prices (Bowbrick, 1988). During the 2005 food crisis in Niger, the media that spread news of rapidly rising prices in Niamey - particularly radio broadcasts in remote rural areas - was accused of contributing to the surge in prices. Also, information disseminated by MIS 
may strengthen collusion (agreements to fix prices) as it can be used to check whether others are complying with the price. Finally, information dissemination by MIS may discourage efforts by market players to discover or acquire new information (Grossman and Stiglitz, 1980). Prices in this case are less and less a reflection of the equilibrium between supply and demand (even though price information is circulating adequately in markets, in part due to MIS) because here very little information is aggregated in the price. The importance of these perverse effects should not be exaggerated for they occur only in fairly exceptional circumstances, but it would probably be very useful to include them in analyses and thus take them into account (thereby minimizing them) when designing MIS.

The third aspect is the impact of MIS on public policy. We have seen that this impact cannot be measured because it would require knowledge of the policies that would have been implemented had policymakers not been provided with MIS information (which of course is impossible). Nevertheless, it would be very useful to develop further research to analyze the process of policy design and implementation and attempt to identify the role played by MIS information. Such analyzes would determine whether information influences decision-making (and if so, in what manner and by what channel). These analyses could thus lead MIS to change their practices to facilitate the consideration of market information in policy-making.

\section{Acknowledgements}

The authors wish to thank AFD and CTA for funding the studies whose results are presented in this article and in this special issue. They would also like to thank MIS operators for their availability and the journal's two reviewers for their very useful comments.

\section{References}

Aker JC, 2010. Information from markets near and far: mobile phones and agricultural markets in Niger. American Economic Journal: Applied Economics $23: 46-59$.
Araujo C, Araujo-Bonjean C, Brunelin S, 2012. Alert at Maradi: preventing food crises by using price signals. World Development 409 : 1882-94.

Bowbrick P, 1988. Are price reporting systems of any use? British Food Journal 90 : 65-9.

Courtois P, Subervie J, 2014. Farmer bargaining power and market information services. American Journal of Agricultural Economics (in press; available on the AJAE website - first published on line: June 22, 2014).

CTA, 2005. Expert consultation on market information systems and agricultural commodities exchanges: strengthening market signals and institutions. Proceedings of an expert meeting held in Amsterdam, Netherlands, 28-30 Nov. 2005. http://ciat-library.ciat.cgiar.org/articulos_ciat/expert consultation market information.pdf

David-Benz H, Egg J, Galtier F, Rakotoson J, Shen $\mathrm{Y}$, Kizito A, 2012. Les systèmes d'information sur les marchés agricoles en Afrique subsaharienne: De la première à la deuxième génération. Focales, 14. Paris : AFD. http://www.afd.fr/webdav/site/ afd/shared/PUBLICATIONS/RECHERCHE/Scientifiques/Focales/14-Focales.pdf

David-Benz H, Rasolofo P, Andriamparany S, 2014. La régulation des prix du riz à Madagascar : I'action conjointe de l'information et de la concertation. Cahiers Agricultures 23 : 295-303. doi : 10.1684/ agr.2014.0707

David-Benz H, Wade I, Egg J, 2005. Market information and price instability: an insight on vegetable markets in Senegal. ISHS Int. Conf., July 19-23, 2005, Chiang Mai.

Duflo E, Glennerster R, Kremer M, 2008. Using randomization in development economics research: a toolkit. In : Schultz P, Strauss JA, eds. Handbook of development economics. Elsevier, edition 1 volume 4, number 5: 3895-962.

Egg J, 1999. Caractérisation des dispositifs d'information pour la sécurité alimentaire dans les pays du Sahel. In : Les systèmes d'information sur la sécurité alimentaire dans le Sahel : diagnostic et perspectives. Paris : Club du Sahel/OCDE, CILSS. http://www.hubrural.org/IMG/pdf/ocde_sim_diagnostic_1999.pdf

Egg J, Galtier F, Grégoire E, 1996. Systèmes d'information formels et informels- La régulation des marchés des céréales au Sahel. Cahiers des Sciences Humaines 32 : 845-68.

Egg J, Galtier F, David-Benz H, 2012. Les NTIC et les SIM : Une nouvelle génération de systèmes d'information sur les marchés agricoles. In : Ledjou JM, Randrianasolo Rakotobe $\mathrm{H}$, eds. Des réseaux et des hommes. Les TIC dans les Suds. Paris: Karthala.

Egg J, Dembélé N, Diarra S, 2014. La décentralisation des systèmes d'information de marché (SIM) une innovation pour répondre aux besoins des acteurs : le cas de l'observatoire du marché agricole (OMA) au Mali. Cahiers Agricultures 23 : 288-94. doi: 10.1684/agr.2014.0713

FACET, 2010. Using ICT to Provide Agriculture Market Price Information in Africa. Technical report, Fostering Agriculture Competitiveness Employing Information Communication Technologies, USAID. https://communities.usaidallnet.gov/ ictforag/node/11

Fackler P, Goodwin B, 2001. Spatial Price Analysis. In: Gardner B, Gordon C., eds. Handbook of Agricultural Economics. Amsterdam : North Holland. http://www.sciencedirect.com/science/handbooks/ $15740072 / 1 /$ part/PB
Fafchamps M, Hill RV, 2008. Price transmission and trader entry in domestic commodity markets. Economic Development and Cultural Change 56 : 729-66.

Fafchamps M, Minten B, 2012. Impact of SMSbased agricultural information on Indian farmers. The World Bank Economic Review 26 : 383-414.

FARA, 2009. Inventaire des services d'information agricoles novateurs utilisant les TIC, Forum pour la recherche agricole en Afrique. Accra: FARA. http://www.fara-africa.org/media/uploads/File/ Announcements/Inventory_French_verOOg.pdf

Ferris $S$, Engoru $P$, Kaganzi E, 2008. Making market information services work better for the poor in Uganda. CAPRI Working paper, $\mathrm{n}^{\circ}$ 77. http://www. capri.cgiar.org/pdf/capriwp77.pdf

Ferris S, Kaganzi E, Engoru P, 2014. Making market information services work better for the poor in Uganda. Cahiers Agricultures 23 : 336-43. doi: 10.1684/agr.2014.0708

Galtier F, 2002. Information, institutions et efficacité des marchés - Trois filières céréalières d'Afrique de l'Ouest analysées comme des systèmes de communication. Thèse de doctorat en économie. Montpellier, Ensam. http://cormas.cirad.fr/pdf/these_FGaltier.pdf

Galtier F, 2013. Managing food price instability in developing countries. A critical analysis of strategies and instruments. With the collaboration of $\mathrm{B}$. Vindel. Paris: AFD. http://www.afd.fr/webdav/site/ afd/shared/PUBLICATIONS/RECHERCHE/Scientifiques/A-savoir/17-VA-A-Savoir.pdf

Galtier F, Egg J, 1998. From price reporting systems to variable geometry oriented market information services. EAAE 57th Seminar "Agricultural Markets beyond Liberalization" Wageningen.

Galtier F, Egg J, 2003. Le paradoxe des systèmes d'information de marché SIM : une clé de lecture issue de l'économie institutionnelle et de la théorie de la communication. Economies et Sociétés, Série $F(41)$ développement, V 7-8/2003 : 1227-60.

Galtier F, Bousquet F, Antona M, Bommel P, 2012a. Markets as communication systems: Simulating and assessing the performance of market networks. Journal of Evolutionary Economics 22 : 161-201.

Galtier F, David-Benz H, Subervie J, Egg J, Staatz J, Dembélé N, et al., 2012b. Strengthening the impact of African agricultural MISs on policies and market efficiency. Policy Brief. Cirad, Inra, Michigan State University, AFD, CTA,Hewlett Foundation. http:// www.sim $2 \mathrm{~g}$.org/index.php/projets en/content/ download/12206/73280/file/Policy\% 20Brief\% 2OMIS.pdf

Galtier F, Clément A, 2014. Réguler le marché par l'information: histoire d'une idée, des Mercantilistes aux systèmes d'information de marché de dernière génération. Cahiers Agricultures 23 : 25969. doi: 10.1684/agr.2014.0714

Goyal A, 2010. Information, direct access to farmers, and rural market performance in Central India. American Economic Journal: Applied Economics $23: 22-45$.

Grossman SJ, Stiglitz JE, 1980. On the impossibility of informationally efficient markets. The American Economic Review 70 : 393-408.

Hayek FA, 1945. The Use of Knowledge in Society. American Economic Review 354 : 519-30. 
Heckman J, 2008. Econometric Causality. International Statistical Review 761 : 1-27.

Imbens GW, Wooldridge JM, 2009. Recent developments in the econometrics of program evaluation. Journal of Economic Literature;(47):5-86.

Jayne TS, Zulu B, Nijhoff JJ, 2006. Stabilizing food markets in Eastern and Southern Africa. Food Policy 31 : 328-41.

Jensen R, 2007. The digital provide : information technology, market performance, and welfare in the South Indian fisheries sector. The Quarterly Journal of Economics 1223 : 879-924.

Kaplan SL, 1996. Le meilleur pain du monde. Paris: Fayard.

Kirzner I, 1992. The Meaning of market process Essays in the Development of Modern Austrian economics. London: Routledge.

Kizito AM, 2011. The structure, conduct, and performance of market information systems in subSaharan Africa. East Lansing (Michigan): Michigan State University. http://etd.lib.msu.edu/islandora/ object/etd\%3A1583/datastream/OBJ/view

Kizito A, Staatz J, 2014. A partial equilibrium approach to estimating the potential payoffs of providing improved agricultural market information in the form of price forecasts. Cahiers Agricultures 23 : 325-8. doi: 10.1684/agr.2014.0709

Maître d'Hôtel E, David-Benz H, Gérard F, 2012. Les politiques de gestion de l'instabilité des prix agricoles: leçons des expériences menées à Madagascar, au Mali et en Zambie. Revue Tiers Monde $21: 71-89$.

Mérel PR, Sexton RJ, Suzuki A, 2009. Optima Investment in Transportation Infrastructure When Middlemen Have Market Power: A DevelopingCountry Analysis. American Journal of Agricultural Economics;(912):462-76.

Moustier P, Nguyen T, Hoang B, 2014. Operation and results of a vegetable market information and consultation system in Vietnam. Cahiers Agricultures 23 : 304-9. doi: 10.1684/agr.2012.0567

Mukhebi A, Kundu J, 2014. Linking farmers to markets in Kenya: The evolving KACE model. Cahiers Agricultures 23 : 282-7. doi: 10.1684 agr.2014.0710

Nakasone E, Torero M, Minten B, 2014. The power of information: The ICT revolution in agricultural development. Annual Review of Resource Economics 6 (in press).

Ngombalu J, Massila G, 2014. Enhancing intraregional grain trade in Eastern Africa through market information systems: the case of the EAGC regional agricultural trade intelligence network (RATIN). Cahiers Agricultures 23 : 270-81. doi: 10.1684/agr.2014.0711

Orléan A, 1989. Pour une approche cognitive des conventions économiques. Revue Economique 40 : 241-72.

Poulton C, Mukwereza L, Chaonwa W, Loader R, Mariga K, Masanganise $P$, et al., 2000. Providing marketing information to smallholders in Zimbabwe: what can the state usefully do? Agrekon;(394):718-29.

Rashid S, Minot N, 2010. Are staple food markets in africa efficient? Spatial price analyses and beyond. Food Security Collaborative Working Papers 58562. East Lansing (Michigan): Michigan State University, Department of Agricultural, Food, and Resource Economics. http://aamp.ifpri.info/ files/2011/06/aampbackgrounddoc_rashid_minot lemma behute january25 30 2010.pdf

Robbins P, 2000. Review of market information systems in Botswana, Ethiopia, Ghana and Zimbabwe. Technical report, Study report for the Technical Centre for Agricultural and Rural Cooperation, Wageningen.

Shen Y, 2009. L'apport des NTIC aux systèmes d'information de marché SIM. Master, université Paris Sud-Faculté Jean Monnet, Paris.

Shepherd A, 1997. Les systèmes d'information sur les marchés : théorie et pratique. Rome: FAO.

Smith V, 1982. Markets as economizers of information: experimental examination of the "Hayek hypothesis. Economic Inquiry 20 : 165-79.

Staatz J, Kizito A, Weber M, Dembélé N, 2014. Challenges in measuring the impact of market information systems. Cahiers Agricultures 23 : 317-24. doi: 10.1684/agr.2013.0631

Subervie J, Galtier F, 2014. L'information sur les prix agricoles par la téléphonie mobile: le cas du Ghana. AFD Document de travail, à paraître.

Staatz JM, Dembélé NN, 2004. Lessons from the Malian MIS Experience. Staff Paper $\mathrm{n}^{\circ} 2004-29$.
East Lansing: Michigan State University-Department of Agricultural Economics.

Svensson J, Yanagizawa D, 2009. Getting prices right : the impact of the market information service in Uganda. Journal of the European Economic Association 72 : 435-45.

Todd PE, 2008. Evaluating social programs with endogenous program placement and selection of the treated. In : Schultz P, Strauss JA, eds. Handbook of development economics. Elsevier, edition 1 volume 4, number 5: 3847-94.

Tollens E, 2002. Market information systems in liberalized African export commodity markets: the case of cocoa and coffee in Côte d'Ivoire, Nigeria, and Cameroon. Working Paper 71. Université catholique, Louvain. http://www.biw.kuleuven. be/aee/clo/wp/tollens2002g.pdf

Tongola I, 2010. The determinants of the use of second generation market information systems in developing countries. A case study of KACE in Kenya. Master, Supagro-Cirad, Montpellier. http:// www.supagro.fr/intranet/memoires/2010 M2SAT TONGOLA.pdf

Vergara O, Wang H, Zuba G, 2014. Agricultural risk modeling to improve market information systems in developing countries. Cahiers Agricultures 23 : 310-6. doi: 10.1684/agr.2014.071

Wade I, 2009. Systèmes d'information de marché, coordination et gestion des risques dans les filières agricoles : cas des produits maraîchers au Sénégal. Thèse de doctorat, Supagro-Université Montpellier I, Montpellier. http://www.bameinfopol.info/IMG/ pdf/These-IWADE_20-01-09_complete.pdf

Wade I, David-Benz H, Egg J, 2004. Information et régulation des filières maraîchères au Sénégal. Cahiers Agricultures 13 : 148-57.

Weber MT, Donovan C, Staatz JM, Dembélé NN, 2005. Guidelines for Building Sustainable Market Information Systems in Africa with Strong PublicPrivate Partnerships. Policy Synthesis $\mathrm{n}^{\circ} 78$ USAID, CIPE. http://fsg.afre.msu.edu/polsyn/number 78.pdf

World Bank, 2012. Information and communication for development 2012: maximizing mobile. Washington (DC): World Bank. http://siteresources.worldbank.org/EXTINFORMATIONANDCOMMUNICATIONANDTECHNOLOGIES/Resources/ IC4D-2012-Report.pdf 